\title{
ANALISIS KEBUTUHAN UNTUK PENGEMBANGAN MODUL INKUIRI BERBASIS PERTANYAAN (MIBP) DI SMP
}

\author{
Desak Made Citrawathi'1, Putu Budi Adnyana², I Made Pasek Anton \\ Santiasa $^{3}$
}

\author{
1,2,3 Jurusan Pendidikan Biologi, \\ Universitas Pendidikan Ganesha, Indonesia
}

E-mail:citrawathi@yahoo.com

\begin{abstract}
Abstrak
Tujuan penelitian ini adalah melakukan analisis kebutuhan untuk pengembangan dan penyusunan modul inkuri berbasis pertanyaan (MIBP). MIBP disusun untuk memfasilitasi pembelajaran sains agar dapat meningkatkan penguasaan konsep biologi, keterampilan proses sains, dan kemampuan berpikir siswa SMP. Pengembangan MIBP menggunakan model ADDIE.Prosedur pengembangan terdiri dari 5 tahap, yaitu 1) Menganalisis, 2) Mendisain, 3) Mengembangkan dan produksi, 4) Mengimplementasikan, dan 5) Mengevaluasi.Penelitian dilakukan dalam waktu 3 tahun. Pada tahun pertama ini dilakukan analisis kebutuhan dan mendisain MIBP. Subjek penelitian adalah guru IPA SMP Negeri dan Swasta di Kecamatan Buleleng.Pengumpulan data dilakukan dengan wawancara, penyebaran angket, observasi, dan dokumentasi.Analisis data dilakukan secara deskriptif dan interpretatif. Dari hasil analisis diperoleh bahwa kurikulum yang digunakan di SMPN 1,SMPN 2, dan SMPN 4 adalah kurikulum 2013, sedangkan di SMP lainnya masih menggunakan kurikulum 2006. Kemampuan guru bertanya untuk meningkatkan keterampilan proses sains, penguasaan konsep, dan kemampuan berpikir belum optimal. Hal ini ditunjukkan dari jenis pertanyaan yang diajukan guru 85,8 persen bersifat konvergen, dan 14,2 persen bersifat divergen. Berdasarkan pertanyaan menurut Taksonomi Bloom, pertanyaan yang diajukan guru 74,4 persen pertanyaan ingatan, 22,6 persen pemahaman, 2,68 persen aplikasi, dan 0,32 persen analisis. Salah satu yang dapat dilakukan untuk meningkatkan kemampuan guru adalah memfasilitasi pembelajarannya dengan MIBP. Dari karakteristik perkembangan kognitifnya, siswa SMP dapat dibelajarkan dengan strategi inkuiri, dan guru setuju dengan pengembangan MIBP.
\end{abstract}

Kata kunci: Kemampuan berpikir, keterampilan proses sains, Modul Inkuiri Berbasis Pertanyaan, penguasaan konsep

\begin{abstract}
The purpose of this study was to analyze the need for the development and preparation of question-based inquiry module (QBIM). QBIMwas designed conceiv to facilitate the learning of science in order to improve the students understanding of biological concept, science process skills, and the ability to think of junior high school students. The module development used ADDIE model. The procedure development consisted of 5 stages, namely 1) Analyze, 2) Design, 3) Develop and production, 4) Implement, and 5) Evaluate. The research carried out within 3 years. In the first year
\end{abstract}


the need analysis and design QBIM were carried out. The subject of research were science teachers at goverment and private high schools in Buleleng District. Data were collected by interview, questionnaire, observation, and documentation. Data analysis was performed descriptively and interpretatively. From the analysis it was found that the curriculum used at junior high school1, 2, and 4 is curriculum 2013, while in the other junior high school the curriculum in use is still curriculum 2006. The ability of teachers to question ask to improve science process skills, mastery of concepts, and the ability to think is not yet optimal.It is shown from the type of questions teachers performed that is convergent 85.8 percent, and 14.2 percent divergence. Based on the questions according to Bloom's Taxonomy, questions that should be proposed by teachers 74.4 percent retention, 22.6 percent understanding, 2.68 percent application, and 0.32 percent analysis. One think that can be done to improve the ability of the teacher is to facilitate learning by QBIM. From the characteristics of cognitive development, junior high school students canbe taught with the strategy of inquiry, and the teachers agree with QBIM development.

Keywords: Ability to think, mastery of concepts, Questions-based Inquiry Module, science process skills.

\section{PENDAHULUAN}

Sekolah pada hakikatnya merupakan tempat guru dan siswa belajar (bukan tempat guru mengajar) dan tempat pengembangan sumber daya insani yang terdidik dan terpelajar. Oleh karena itu, peran utama guru adalah sebagai agen pembelajaran untuk menyiapkan lingkungan belajar yang memungkinkan siswa belajar aktif secara mental yakni aktif berpikir (minds-on) dan aktif secara fisik atau aktif bekerja (hands-on). Belajar sangat penting untuk mengembangkan pengetahuan dan menghadapi hidup dan kehidupan yang semakin kompleks. Hal ini sesuai dengan pendapat Gredler (1991) yang menguraikan bahwa belajar adalah proses seseorang memperoleh berbagai kecakapan, keterampilan dan sikap. Untuk itu diperlukan sumber belajar yang dapat memfasilitasi siswa belajar secara efektif. Tugas guru bukan memberikan pengetahuan yang harus dihafalkan oleh siswa tetapi menyiapkan lingkungan belajar yang memungkinkan siswa membangun pengetahuannya secara aktif. Belajar merupakan suatu proses perubahan tingkah laku sebagai hasil interaksi dengan lingkungannya dalam memenuhi kebutuhannya. Belajar adalah suatu proses usaha yang dilakukan individu untuk memperoleh suatu perubahan tingkah laku secara baru, keseluruhan sebagai hasil pengalaman individu tersebut dalam interaksi dengan lingkungannya (Slameto, 1988). Belajar merupakan proses penting bagi perubahan perilaku manusia dan belajar mencakup segala sesuatu yang dipikirkan dan dikerjakan. Belajar juga memegang peranan penting di dalam perkembangan, kebiasaan, sikap, keyakinan, tujuan, kepribadian, dan bahkan persepsi manusia (Anni \& others, 2004). Sedangkan menurut Morgan et al. dalam (Anni \& others, 2004) belajar merupakan perubahan relatif permanen yang terjadi karena hasil dari praktik atau pengalaman. Winkel dalam Wena (2009) mendefinisikan belajar sebagai suatu aktivitas mental atau psikis yang berlangsung dalam interaksi aktif dengan lingkungan, yang menghasilkan 
perubahan dalam pengetahuan, pemahaman, ketrampilan, dan nilai sikap. Belajar paling baik berlangsung apabila peran guru tidak dominan. Belajar yang didominasi guru akan menyebabkan siswa belajar sedikit sekali (Frangenheim, 2005; Semiawan, Belen, \& Tangyong, 1989).

Hakikat belajar sains adalah mempelajari alam sekitar dengan caracara ilmiah. Untuk itu, siswa perlu diberikan pengalaman belajar yang dapat mengembangkan kemampuan berpikir, keterampilan proses dan sikap ilmiah. Hal ini sesuai dengan tuntutan standar isi mata pelajaran sains di SMP. Peran pertanyaan dan strategi berpikir sangat penting untuk pemberdayaan berpikir siswa. Hal ini sesuai dengan pendapat Frangenheim (2005) yang menguraikan bahwa "learners are empowered when they understand the level of the question, understand the expected outcome, and know which appropriate strategy/tool to employ". Perkembangan ilmu pengetahuan yang sangat cepat tidak memungkinkan guru membelajarkan seluruh konsep dan prinsip sains secara bermakna. Oleh karena itu, guru sebaiknya memberikan cara untuk menemukan pengetahuan (learn how to learn). Belajar bagaimana belajar sangat bermanfaat bagi siswa dan memungkinkan siswa belajar sepanjang hayat.

Peraturan Menteri Pendidikan Nasional Republik Indonesia nomor 22 tahun 2006 tentang Standar Isi untuk Satuan Pendidikan Dasar dan Menengah, menguraikan bahwa pendidikan sains di SMP diarahkan untuk inkuiri dan berbuat sehingga dapat membantu peserta didik untuk memperoleh pemahaman yang lebih mendalam tentang alam sekitar. Proses pembelajaran sains diharapkan dilaksanakan menggunakan pembelajaran inkuiri ilmiah untuk menumbuhkan kemampuan berpikir, bekerja dan bersikap ilmiah serta mengomunikasikannya sebagai aspek penting kecakapan hidup. Rauf, Rasul, Mansor, Othman, \& Lyndon (2013) menyebutkan bahwa guru memainkan peran penting untuk mengajarkan keterampilan proses sains di kelas melalui perencanaan dan mengatur kegiatan belajar dan mengajar. Oleh karena itu, pembelajaran sains di SMP menekankan pada pemberian pengalaman belajar secara langsung melalui penggunaan dan pengembangan keterampilan proses dan sikap ilmiah.

Berdasarkan hasil wawancara, observasi, analisis rencana pelaksanaan pembelajaran (RPP) dan analisis bahan ajar yang digunakan guru sains (biologi) SMP di Kota Singaraja dapat diidentifikasi adanya diskrepansi dan permasalahan bahwa: (a) Pembelajaran masih menekankan pada penguasaan konsep dan prinsip sains (biologi) bukan proses berpikir dan bagaimana cara menemukannya. Proses berpikir perlu dibelajarkan secara sistematis mulai level rendah ke level tinggi. Hal ini sesuai dengan pendapat Fragenheim (2005) yang menguraikan bahwa berpikir tidak terjadi secara otomatis perlu dilatih dengan menggunakan strategi berpikir khusus, (b) Keterampilan proses tidak didesain secara sistematis. Keterampilan proses perlu dibelajarkan karena dapat mengembangkan pengetahuan dan keterampilan (Funk \& others, 1985). Keterampilan proses merupakan sarana untuk membelajaran siswa menemukan konsep dan prinsip sains atau 
mendapatkan ilmu yang dibelajarkan. Di samping itu, keterampilan proses dapat digunakan dalam kehidupan sehari-hari, seperti mengamati dengan baik, mengklasifikasi benda atau yang lain, membuat keputusan yang tepat berdasarkan data dan keterampilan lain.

Hal ini sesuai dengan pendapat Carin (1993) yang menyatakan keterampilan proses sebagai keterampilan belajar sepanjang hayat (lifelong learning skills). Pengetahuan terus berkembang dan guru tidak mungkin akan mampu menyajikan seluruh dengan bekal keterampilan proses dapat meng-update pengetahuan secara kontinyu, (c) Keterampilan bertanya guru belum optimal. Keterampilan bertanya merupakan inti dari pembelajaran berbasis inkuiri. Pertanyaan dapat menuntun untuk melakukan penyelidikan sebagai usaha siswa dalam memahami materi yang dipelajari, dan (d) Keterampilan bertanya guru dapat dilatihkan antara lain dengan menyiapkan bahan ajar berbasis pertanyaan. Bahan ajar seperti modul inkuiri berbasis pertanyaan belum ada. Untuk mengatasi diskrepansi dan permasalahan di atas, perlu dikembangkan modul inkuiri berbasis pertanyaan (MIBP). Modul merupakan salah satu perangkat pembelajaran yang dapat memfasilitasi siswa belajar karena mengandung tujuan yang jelas, materi pokok, lembar kegiatan, dan dapat mengecek pemahamannya secara mandiri (selfassessment). Modul telah terbukti dapat meningkatkan penalaran dan keterampilan inkuiri (Adnyana \& Citrawathi, 2008).

Berdasarkan uraian di atas, maka permasalahan yang dikaji dalam penelitian ini adalah sebagai berikut.1.
Bagaimakah karakteritik siswa SMP? 2. Bagaimanakah karakteristik kurikulum sains SMP? 3. Bagaimakah jenis pertanyaan guru dalam pembelajaran sains di SMP? 4. Apakah hambatan yang dialami guru sains SMP dalam mengajukan pertanyaan untuk memberdayakan kemampuan beripikir dan keterampilan proses sains? 5. Bagaimana pendapat guru tentang pengembangan modul inkuiri berbasis pertanyaan untuk pembelajaran sains di SMP?

\section{METODE}

Penelitian ini menggunakan model pengembangan Borg \& Gall (1989). Pengembangan Modul Inkuiri Berbasis Pertanyaan (MIBP) mengggunakan ADDIE Model.Pemilihan model ini karena mengembangkan bahan ajar (modul) identik dengan prosedur kegiatan mengajar. ADDIE Model terdiri dari 5 tahapan, yaitu tahah Analisis (Analysis), tahap Perancangan (Design), tahap Pengembanagan dan Produksi (Development and Production), tahap Implementasi (Implementation), dan tahap Evaluasi (Evaluation) (Colston, 2012; Kruse, 2002; Molenda, 2003).

Tahapan Pengembangan MIBP pada tahun pertama diuraikan secara ringkas seperti berikut: 1) Tahap Analisis (Analysis), Pada tahap ini dilakukan analisis kompetensi (kurikulum), analisis karakteristik siswa, dan analisis instruksional; 2) Tahap Perancangan (Design), Hasil analisis digunakan dalam membuat format MIBP, menentukan topik, dan merancang MIBP; 3) Tahap Pengembangan dan Produksi (Development \& Production), Kegiatan yang dilakukan pada tahap ini adalah: a) 
Pra Penulisan MIBP (pengakajian pustaka, pengumpulan bahan), dan b) Penulisan prototipe MIBP. Subjek penelitian adalah guru IPA SMP Negeri dan Swasta yang ada di Kota Singaraja Bali. Jumlah sekolah yang dilibatkan adalah 10 sekolah yang terdiri dari lima SMP Negeri dan lima SMP Swasta.

Pengumpulan data dilakukan dengan cara sebagai berikut: 1) Wawancara mendalam dengan guru IPA (Biologi) dari lima SMPN (SMPN 1, SMPN 2, SMPN 3, SMPN 4, dan SMPN 6), dan lima SMP Swasta (SMP Lab Undiksha, SMP Bhaktiyasa, SMP Mutiara, SMP Santo Paulus, dan SMP Saraswati) yang ada di kota Singaraja. Wawancara mendalam dilaksanakan dengan mengajukan pertanyaan sebagai pembuka, dan kemudian memancing sebanyak-banyaknya jawaban dari responden. Wawancara ini dilakukan untuk mendapatkan data tentang pelaksanaan pembelajaran sains di sekolah masing-masing; 2) Angket. Angket diberikan kepada guru dengan tujuan untuk mengetahui karakteristik siswa, buku yang digunakan, dan pertanyaan-pertanyaan yang sering dikemukakan guru dan siswa pada pembelajaran IPA di SMP. Angket ini diisi sendiri oleh guru (self administered); 3) Observasi. Observasi dilakukan di kelas untuk mendapatkan data tentang : a) jenis pertanyaan yang diajukan guru dan siswa dalam pembelajaran sains dan b) aktivitas belajar siswa; 4) Dokumentasi. Data yang dikumpulkan melalui dokumentasi meliputi data tentang kurikulum, Silabus, dan RPP yang dibuat guru sains SMP dan hasil belajar siswa. Data kualitatif dan kuantitatif yang diperoleh dianalisis secara deskriptif dengan cara menyusun data secara sistematis, mengorganisasi data ke dalam kategori, melakukan sintesis menyusun dalam pola tertentu, dan membuat kesimpulan.

\section{HASIL DAN PEMBAHASAN}

Dari pencatatan dokumen diperoleh umur siswa SMP berkisar antara 13 sampai dengan 15 tahun. Siswa SMP pada kisaran usia antara 1315 tahun, termasuk kelompok yang mengalami tahap perkembangan pubertas atau remaja awal sampai remaja pertengahan yang proses perkembangan psikologisnya perlu mendapat perhatian dari orang tua (keluarga), guru (sekolah), dan masyarakat. Dengan memahami karakteristik perkembangan kelompok siswa ini, guru dapat merancang strategi pembelajaran yang dapat membantu proses perkembangan siswa secara optimal.

Kurikulum yang berlaku di SMPN 1 , SMPN 2, dan SMPN 4 adalah kurikulum 2013.Sedangkan di SMP lainnya masih berlaku kurikulum 2006. Kurikulum 2013 di Kelas VII terdiri dari empat kompetensi inti, yaitu: $\mathrm{KI}$ 1. Menghargai dan menghayati ajaran agama yang dianutnya; KI 2. Menghargai dan menghayati perilaku jujur, disiplin, tanggungjawab, peduli (toleransi, gotong royong), santun, percaya diri, dalam berinteraksi secara efektif dengan lingkungan sosial dan alam dalam jangkauan pergaulan dan keberadaannya; KI 3. Memahami pengetahuan (faktual, konseptual, dan prosedural) berdasarkan rasa ingin tahunya tentang ilmu pengetahuan, teknologi, seni, budaya terkait fenomena dan kejadian tampak mata; $\mathrm{KI} 4$. Mencoba, mengolah, dan menyaji dalam 
ranah konkret (menggunakan, mengurai, merangkai, memodifikasi, dan membuat) dan ranah abstrak (menulis, membaca, menghitung, menggambar, dan mengarang) sesuai dengan yang dipelajari di sekolah dan sumber lain yang sama dalam sudut pandang/teori.

Materi pokok IPA yang dibelajrkan di Kelas VII adalah: (a) Objek IPA dan Pengamatannya, (b) Klasifikasi Benda, (c) Klasifikasi Makhluk Hidup, (d) Sistem Organisasi Kehidupan, (e) Karakteristik Zat, (f) Energi dalam Sistem Kehidupan, (g) Suhu dan Perubahannya, (h) Interaksi Makhluk Hidup dan Lingkungannya, (i) Dampak Pencemaran bagi Kehidupan, dan (j) Pemanasan Global dan Ekosistem. Sedangkan materi pokok pada kelas VIII adalah: (a) Gerak pada makhluk hidup dan benda, (b) Struktur tumbuhan dan memanfaatannya dalam teknologi, (c) Sifat bahan dan kesehatan, (d) Sitem gerak pada manusia, (e) Sistem pencernaan makanan dan kaitannya dengan sistem tubuh, (f) Bahan kimia dalam kehidupan, (g) Tekanan zat cair dan penerapannya dalam kehidupan sehari-hari, (h) Sistem ekskresi pada manusia, (i) Getaran, gelombang, dan bunyi, (j) Cahaya dan alat optik, (k) Gunung api, (I) Tata surya, dan (m) Gerak bumi, bulan, terhadap matahari.

Data yang diperoleh dari penelitian ini berupa pertanyaanpertanyaan yang diajukan oleh guru dalam proses pembelajaran. Pertanyaan-pertanyaan tersebut dianalisis lebih lanjut berdasarkan jenis pertanyaan terbuka-tertutup, pertanyaan untuk me melakukan proses inkuiri dan melatih keterampilan proses sains, serta tingkatan kognitif yang dituntutnya.
Pertanyaan-pertanyaan yang mengarah pada pembentukan pengetahuan selanjutnya dianalisis berdasarkan kemungkinan jawaban yang diharapkan dari pertanyaan tersebut. Berdasarkan hasil analisis jenis pertanyaan tertutup-terbuka dapat diketahui bahwa dari 36 pertanyaan, 31 pertanyaan $(86,11 \%)$ pertanyaan membentuk pengetahuan yang diajukan guru di kelas adalah jenis pertanyaan tertutup sedangkan sisanya yakni 5 pertanyaan $(13,89 \%)$ adalah pertanyaan terbuka. Banyaknya pertanyaan tertutup menunjukkan bahwa pertanyaan guru hanya menuntut jawaban yang pasti dan tertentu. Sedikitnya jumlah pertanyaan terbuka menunjukkan bahwa pertanyaan yang diajukan guru dalam proses pembelajaran kurang mendorong siswa untuk berpikir. Hal ini juga didukung dengan kenyataan bahwa sebagaian besar pertanyaan yang diajukan guru berada dalam jenjang kognitif tingkat rendah

Pertanyaan dapat diklasifikasikan dalam berbagai proses kognitif seperti yang dikemukakan dalam taksonomi Bloom. Dalam versi revisi taksonomi Bloom (Anderson et al., 2001) dilakukan pemisahan antara dimensi pengetahuan (knowledge) dan dimensi proses kognitif. Dimensi pengetahuan mencakup pengetahuan faktual, pengetahuan konseptual, pengetahuan prosedural dan pengetahuan metakognitif. Dimensi proses kognitif mencakup menghafal (remember), memahami (understand), menerapkan (apply), menganalisis (analyse), mengevaluasi (evaluate), dan membuat (create). Dari dimensi pengetahuan, 20 pertanyaan $(55,56 \%)$ termasuk pertanyaan pengetahuan faktual, 14 pertanyaan $(38,89 \%)$ tentang 
pengetahuan konseptual, dan 2 pertanyaan $(5,55 \%)$ tentang pengetahuan prosedural. Pertanyaan pengetahuan metakognitif tidak atau belum ada disampaikan oleh guru. Hasil ini menunjukkan bahwa pengetahuan prosedural yang erat kaitannya dengan keterampilan bekerja ilmiah belum mendapat perhatian dalam pelajaran sains. Berdasarkan hasil analisis pertanyaan berdasarkan jenjang kognitif taksonomi Bloom diketahui bahwa jumlah rata-rata pertanyaan bersifat mengingat adalah 27 pertanyaan (75\%), jumlah rata-rata pertanyaan bersifat memahami adalah 5 pertanyaan $(13,89 \%)$, jumlah rata-rata pertanyaan bersifat aplikasi adalah $3(8,33 \%)$, dan jumlah rata-rata pertanyaan bersifat analisis adalah 1 (2,78\%). Pertanyaan bersifat evaluasi dan pertanyaan membuat (create) adalah $0 \%$. 3 . Pertanyaan untuk proses inkuiri dan pembelajaran keterampilan proses sains Hasil observasi di kelas menunjukan bahwa pertanyaan terkait keterampilan inkuiri dan keterampilan proses sains masih kurang. Pertanyaan keterampilan proses sains yang diajukan terkait keterampilan mengamati, mengukur, mengomunikasikan, dan menginferensi.

Hambatan yang dihadapi guru dalam mengajukan pertanyaan antara lain kurangnya pemahaman guru tentang jenis-jenis pertanyaan untuk proses inkuiri dan kurangnya perencanaan guru tentang pertanyaan yang akan diajukan dalam pembelajaran. Oleh karena itu guru setuju dengan pengembangan Modul Inkuiri Berbasis Pertanyaan (MIBP).

Hasil tanggapan guru terhadap penyebaran kuesioner dan wawancara terkait pengembangan modul inkuiri berbasis pertanyaanadalah sebagai berikut: a) Modul sangat dibutuhkan oleh guru dalam membelajarkan sains di SMP; b) Pengalaman belajar untuk melatih keterampilan proses sains siswa perlu dirancang dan diberikan pada siswa; c) Pertanyaan yang medorong siswa belajar dan melatih keterampilan perlu dirancang dengan baik; d) Sangat setuju dikembangkan modul inkuiri berbasis pertanyaan (MIBP).

Ditinjau dari teori perkembangan kognitif dari Piaget, siswa SMP dengan usia antara 13-15 tahun mencapai tahap operasional formal (operasi = kegiatankegiatan mental tentang berbagai gagasan). Siswa sudah dapat berpikir logis tentang berbagai gagasan abstrak, sistematisdan ilmiah untuk memecahkan masalah (Yusuf, 2004). Salah satu karakteristik yang menandai perkembangan operasional formal adalah penalaran hipotetis-deduktif. Ciri penalaran hipotetis-deduktif antara lain: (1) Dapat merumuskan banyak hipotesis yang memiliki kaitan, memiliki logika kombinatorial, menalar dengan konsepkonsep dan hubungan-hubungan yang konkrit dan abstrak, menalar tentang sifat-sifat dan teori-teori yang abstrak; (2) Diberikan satu perangkat kondisi, tujuan dan sumber daya, dapat merencanakan prosedur panjang dan kompleks; (3) Sadar dan kritis terhadap penalarannya sendiri, dapat menunjukkan penampilan reflektif atas proses pemecahan masalah dan memeriksa kesimpulan-kesimpulan dengan pengecekan sumber-sumber, penggunaan informasi lain yang diketahui, atau mencari pemecahan masalah dari sudut pandang lain (Nur, 2004). Perkembangan kognitif siswa SMP yaitu tahap operasional formal 
memungkinkan untuk dibelajarkan dengan strategi pembelajaran inkuiri.

Kurikulum 2013 merupakan

kurikulum berbasis kompetensi, yang menekankan pada sikap, pengetahuan, dan keterampilan. Berdasarkan Peraturan Menteri Pendidikan dan Kebudayaan Republik Indonesia No 65 Tahun 2013 tentang Standar Proses Pendidikan Dasar dan Menengah, proses pembelajaran diarahkan pada pengembangan ketiga ranah tersebut secara utuh/holistik. Dengan demikian kualitas pembelajaran secara utuh melahirkan pribadi yang mencerminkan keutuhan penguasaan sikap, pengetahuan dan keterampilan.Sikap diperoleh melalui aktivitas "menerima, menghargai, menghayati, dan mengamalkan". Pengetahuan diperoleh dari aktivitas mengingat, memahami, menerapkan, menganalisis, mengevaluasi dan mencipta. Sedangkan keterampilan diperoleh melalui aktivitas mengamati, menanya, mencoba, menalar, menyaji, dan mencipta.

Struktur kurikulum 2013 untuk Sekolah Menengah Pertama berdasarkan Peraturan Menteri Pendidikan dan Kebudayaaan Nomor 68 Tahun 2013, dirumuskan Kompetensi Inti, yaitu: (1) Kompetensi Inti-1(KI-1) untuk kompetensi inti sikap spiritual, (2) Kompetensi Inti-2 (KI-2) untuk kompetensi inti sikap sosial, (3) Kompetensi Inti-3 (KI-3) untuk kompetensi inti pengetahuan, dan (4) Kompetensi Inti-4 (KI-4) untuk kompetensi inti keterampilan.

Hasil penelitian menunjukkan pertanyaan lebih dominan pada pertanyaan bersifat tertutup dan yang bersifat terbuka sangat sedikit. Hasil ini sejalan dengan temuan terdahulu
(Ermasari, Subagia, \& Sudria, 2014) bahwa sebagian besar pertanyaan yang ditanyakan guru merupakan pertanyaan tertutup. Banyaknya pertanyaan tertutup menunjukkan bahwa pertanyaan guru hanya menuntut jawaban yang pasti dan tertentu. Sedikitnya jumlah pertanyaan terbuka menunjukkan bahwa pertanyaan yang diajukan guru dalam proses pembelajaran kurang mendorong siswa untuk berpikir. Hal ini juga didukung dengan kenyataan bahwa sebagaian besar pertanyaan yang diajukan guru berada dalam jenjang kognitif tingkat rendah. Ini berarti bahwa pertanyaan terkait keterampilan proses sains masih rendah.

Sebagian besar pertanyaan yang diajukan guru merupakan pertanyaan pada jenjang kognitif tingkat rendah (hafalan dan pemahaman) dan hanya sedikit sekali yang berada pada jenjang kognitif tingkat tinggi. Walaupun pertanyaan ingatan dan pemahaman merupakan dasar dari berpikir tingkat tinggi tetapi pengembangan dari pertanyaan ingatan yang terlalu berlebihan dan tidak diimbangi dengan pertanyan kognitif tingkat tinggi akan kurang baik karena bagaimanapun juga pertanyaan yang memberikan konstribusi yang lebih baik dalam proses pembelajaran adalah pertanyaan kognitif tingkat tinggi. Berdasarkan analisis sejumlah penelitian tentang dampak penggunaan pertanyaan, Anderson et al. (2001) menemukan bahwa pada pertanyaan faktual lebih efektif untuk meningkatkan pencapaian untuk siswa masih muda dan kurang kemampuannya sedangkan penekanan pada pertanyaan kognitif tingkat tinggi lebih efektif untuk siswa rata-rata atau yang kemampuannya tinggi. Karena siswa 
yang terlibat dalam penelitian ini adalah siswa kelas 7 (usia 13 tahun) tampaknya guru harus lebih memvariasikan lagi jenjang kognitif pertanyaannya sehingga siswa juga dirangsang untuk berpikir.

Pemberian pertanyaan sangat bermanfaat dalam pembelajaran. Cotton (2001) menguraikan bahwa tujuan bertanya ada 7 , yaitu untuk: 1) mengembangkan minat dan motivasi siswa menjadi terlibat aktif dalam pembelajaran, 2) mengevaluasi kesiapan, mengecek pekerjaan rumah atau tugas, 3) mengembangkan keterampilan berpikir kritis dan sikap inkuiri, 4) untuk mengulangi dan meringkas pelajaran sebelumnya, 5) pengembangan wawasan dengan mengaitkan dengan hal yang baru, 6) mengases pencapaian tujuan pembelajaran, 7) mendorong siswa untuk berburu pengetahuan sendiri. Di samping itu, Gulo (2008) dan Trowbridge \& Bybee (1990) menguraikan berberapa peranan bertanya antara lain berperan untuk meningkatkan kadar CBSA, sikap inkuiri, dan membantu siswa berpikir.

Hambatan yang di alami dalam pembelajaran perlu diatasi atau dicarikan solusi. Pembelajaran merupakan suatu kegiatan utama pendidikan yang menentukan kualitas pendidikan. Sesuai dengan hakikat sains, belajar sains tidak hanya memberikan pengetahuan sains saja, tetapi memberikan pengalaman belajar melatih keterampilan proses sains dan sikap ilmiah. Salah satu solusi yang dapat ditempuh adalah dengan menerapkan pembelajaran berbasis inkuiri. Inkuiri lebih menekankan pada "how we come to know" dan mengurangi pada "what we know". Dalam pembelajaran berbasis inkuiri, siswa lebih dilibatkan aktif dalam mengonstruksi pengetahuan daripada mengonsumsi pengetahuan.

Berdasarkan hasil penelitian dapat diintepretasikan bahwa guru sains SMP memberikan pendapat positif terhadap pengembangan MIPB. Hal ini disebabkan karena diyakini bahwa modul sebagai salah satu bahan ajar dan perangkat pembelajaran memiliki banyak manfaat dalam memotivasi siswa belajar secara mandiri. Aktivitas belajar dapat dikemas agar siswa dapat melakukan inkuri (penyelidikan), sehingga mengembangkan keterampilan proses sains dan pemahaman konsep lebih baik.

\section{SIMPULAN DAN SARAN}

Berdasarkan hasil penelitian tahun pertama yang telah dilaksanakan dapat dibuat beberapa kesimpulan sebagai berikut: 1) Karakteristik peserta didik di SMP adalah memiliki umum 1315 tahun, memasuki masa pubertas (remaja awal), dan mememungkinkan untuk dibelajarkan dengan pembelajaran berbasis inkuiri; 2) Kurikulum yang digunakan di SMPN 1, SMPN 2, dan SMPN 4 di Kota Singaraja adalah kurikulum 2013, sedangkan di SMP lainnya masih menggunakan kurikulum 2006. Materi pokok yang dibelajarkan di kelas VIII meliputi materi pokok pada kelas VIII adalah: (a) Gerak pada makhluk hidup dan benda, (b) Struktur tumbuhan dan memanfaatannya dalam teknologi, (c) Sifat bahan dan kesehatan, (d) Sitem gerak pada manusia, (e) Sistem pencernaan makanan dan kaitannya dengan sistem tubuh, (f) Bahan kimia dalam kehidupan, (g) Tekanan zat cair dan penerapannya dalam kehidupan sehari-hari, (h) Sistem ekskresi pada manusia, (i) Getaran, 
gelombang, dan bunyi, (j) Cahaya dan alat optik, (k) Gunung api, (I) Tata surya, dan (m) Gerak bumi, bulan, terhadap matahari; 3) Pertanyaan yang dikemukakan guru lebih bersifat konvergen, didominasi oleh pertanyaan tingkatan berpikir tinggkat rendah, dan kurang memberikan pertanyaan terkait keterampilan proses sains; 4) Hambatan yang dialami guru sains SMP dalam mengajukan pertanyaan untuk memberdayakan kemampuan beripikir dan kertemapilan proses sains adalah a) kurangnya pemahaman guru tentang jenis-jenis pertanyaan untuk proses inkuiri, b) kurangnya kemampuan guru dalam merencanakan dan membuat pertanyaan yang akan diajukan dalam pembelajaran, dan 3) guru kurang memahami peranan pertanyaan dalam pembelajaran sains; 5) Guru berpendapat bahwa perlu dikembangankan Modul Inkuiri Berbasis Pertanyaan (MIBP) untuk membantu siswa memahami konsep sains dan melatih eterampilan proses sains.

Saran yang dapat diusulkan berdasarkan hasil penelitian ini adalah: 1) Guru perlu memiliki pengetahuan dan keterampilan menggunakan pertanyaan dalam pembelajaran sains; 2) Perlu dikembangkan atau disusun bahan ajar yang dapat membantu guru dan siswa dalam belajar sains untuk meningkatkan pemahaman konsep dan keterampilan proses sains; 3) Guru diberikan pelatihan tentang keterampilan bertanya yang dapat meningkatkan keterampilan proses sains siswa.

\section{DAFTAR PUSTAKA}

Adnyana, P. B., \& Citrawathi, D. M. (2008). Pengembangan Modul Biologi Berorientasi Siklus Belajar untuk Meningkatkan Penalaran dan Keterampilan inkuiri Siswa SMA. Jurnal Penelitian Dan Pengembangan Pendidikan, 2(3), 556-565.

Anderson, L. W., Krathwohl, D. R., Airasian, P., Cruikshank, K., Mayer, R., Pintrich, P., ... Wittrock, M. (2001). A taxonomy for learning, teaching and assessing: A revision of Bloom's taxonomy. New York. Longman Publishing. Artz, AF, \& Armour-Thomas, E.(1992). Development of a CognitiveMetacognitive Framework for Protocol Analysis of Mathematical Problem Solving in Small Groups. Cognition and Instruction, 9(2), 137-175.

Anni, C. T., \& others. (2004). Psikologi belajar. Semarang: Unnes Press.

Borg, W. R., \& Gall, M. D. (1989). Educational Research. New York: Longman.

Carin, A. A. (1993). Teaching modern science. Simon \& Schuster Books For Young Readers.

Colston, R. (2012). ADDIE Model.

Cotton, K. (2001). Classroom questioning. School Improvement Research Series, 3.

Ermasari, G., Subagia, I. W., \& Sudria, I. B. N. (2014). Kemampuan bertanya guru IPA dalam pengelolaan pembelajaran. Jurnal Pendidikan IPA Indonesia, 4(1).

Frangenheim, E. (2005). Reflections on classroom thinking strategies: Practical strategies to encourage thinking in your classroom. Paul Chapman Educational Publishing. 
Funk, H. J., \& others. (1985). Learning science process skills. ERIC.

Gredler, M. E. (1991). Belajar dan membelajarkan. Rajawali Pers, Jakarta.

Gulo, W. (2008). Strategi Belajar Mengajar. Grasindo.

Kruse, K. (2002). Introduction to instructional design and the ADDIE model. Retrieved January, 26, 2005.

Molenda, M. (2003). In search of the elusive ADDIE model. Performance Improvement, 42(5), 34-37.

Rauf, R. A. A., Rasul, M. S., Mansor, A. N., Othman, Z., \& Lyndon, N. (2013). Inculcation of science process skills in a science classroom. Asian Social Science, 9(8), 47.
Semiawan, C., Belen, S., \& Tangyong, A. F. (1989). Pendekatan Ketrampilan Proses: Bagaimana Mengaktifkan Siswa dalam Belajar? Gramedia.

Slameto. (1988). Belajar dan Faktorfaktor yang Mempengaruhinya. Bina Aksara.

Trowbridge, L. W., \& Bybee, R. W. (1990). Becoming a secondary school science teacher.

Wena, M. (2009). Strategi pembelajaran inovatif kontemporer. Jakarta: Bumi Aksara.

Yusuf, S. (2004). Psikologi perkembangan anak dan remaja (Vol. 197). Bandung: Remaja Rosdakarya. 